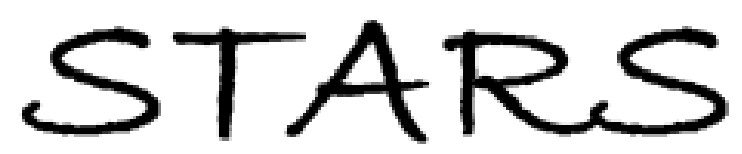

University of Central Florida

STARS

8-1-2008

\title{
Very Low Energy Homes In The United States: Perspectives On Performance From Measured Data
}

\author{
Florida Solar Energy Center
}

Danny Parker

Florida Solar Energy Center, dparker@fsec.ucf.edu

Part of the Energy Systems Commons

Find similar works at: https://stars.library.ucf.edu/fsec

University of Central Florida Libraries http://library.ucf.edu

This Research Report is brought to you for free and open access by STARS. It has been accepted for inclusion in FSEC Energy Research Center® by an authorized administrator of STARS. For more information, please contact STARS@ucf.edu.

\section{STARS Citation}

Florida Solar Energy Center and Parker, Danny, "Very Low Energy Homes In The United States:

Perspectives On Performance From Measured Data" (2008). FSEC Energy Research Center®. 398.

https://stars.library.ucf.edu/fsec/398

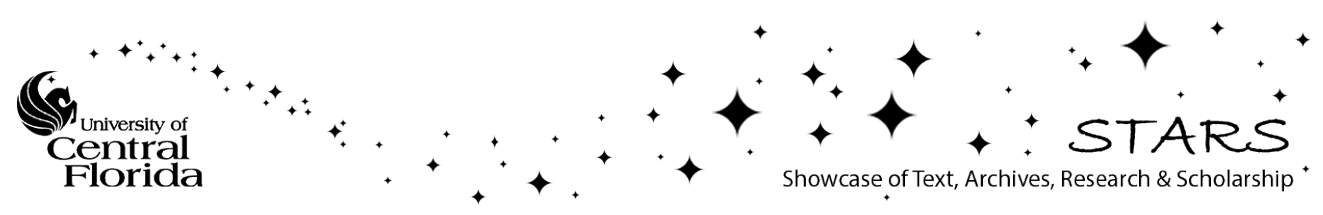




\section{Very Low Energy Homes in the United States: Perspectives on Performance from Measured Data}

\section{Authors}

Danny S. Parker

\section{Original Publication}

Parker, D., " Very Low Energy Homes in the United States: Perspectives on Performance from Measured Data", Prepared for the National Academy of Sciences and submitted to Energy \& Buildings, August 2008.

\section{Publication Number}

FSEC-RR-302-08

\section{Copyright}

Copyright (C) Florida Solar Energy Center/University of Central Florida 1679 Clearlake Road, Cocoa, Florida 32922, USA

(321) 638-1000

All rights reserved.

\section{Disclaimer}

The Florida Solar Energy Center/University of Central Florida nor any agency thereof, nor any of their employees, makes any warranty, express or implied, or assumes any legal liability or responsibility for the accuracy, completeness, or usefulness of any information, apparatus, product, or process disclosed, or represents that its use would not infringe privately owned rights. Reference herein to any specific commercial product, process, or service by trade name, trademark, manufacturer, or otherwise does not necessarily constitute or imply its endorsement, recommendation, or favoring by the Florida Solar Energy Center/University of Central Florida or any agency thereof. The views and opinions of authors expressed herein do not necessarily state or reflect those of the Florida Solar Energy Center/University of Central Florida or any agency thereof. 


\title{
Very Low Energy Homes in the United States: Perspectives on Performance from Measured Data
}

\author{
Danny S. Parker \\ Florida Solar Energy Center, 1679 Clearlake Rd., Cocoa, FL 32922, USA \\ Telephone: 321/638-1405; Fax: 321/638-1439; E-mail address: dparker@fsec.ucf.edu \\ Prepared for the National Academy of Sciences and submitted to Energy \& Buildings
}

\begin{abstract}
$\underline{\text { Abstract }}$
We present measured annual performance data from a dozen recent-vintage very low energy homes in North America. Many of the designs combine greater energy efficiency with solar electric photovoltaic power in an attempt to create Zero Energy Homes (ZEH). We also provide measured data from the first home constructed to the German Passivhaus standard in the United States. Several projects either exceeded or come very close to true net zero energy when evaluated over a year.

The data indicate that very low energy use buildings can very readily be achieved in North America. Annual energy use half that or less than standard housing can be achieved for an equivalent cost of $\$ 0.10 / \mathrm{kWh}$ from the efficiency investment. In general, the better cost effectiveness seen from energy efficiency measures indicates that greater investment in conservation should be a prerequisite to installation of solar water heating and solar electricity in Zero Energy Homes. However, over emphasis in efficiency is also possible. This suggests that optimization tools such as BEOpt, which characterize both renewable resource performance and that also of specific combinations of energy efficiency measures, will best guide designers to locate the most economically favorable mix to reach an energy neutral level.
\end{abstract}

$\underline{\text { Keywords }}$

Low energy homes, zero energy homes, monitoring, Passivhaus, energy performance

The Residential Sector in Perspective

Currently, the residential sector in the U.S. uses approximately 20 quadrillion Btu of site energy per year; this amounts to approximately $20 \%$ of all energy use in the nation and $27 \%$ when confined to the non-transportation sector. Moreover, American households consumed fully $35 \%$ of all national electricity production (3,660 Billion kWh) and strongly depend on natural gas for heating [1].

Further, supplying energy to the residential sector in the U.S. generates fully $18 \%$ of its greenhouse gas emissions. Despite technological improvements in refrigerator, furnace efficiency and energy codes improving insulation, many American lifestyle changes have put higher demands on heating and cooling resources. For instance, the average size of 
homes built in the United States has increased significantly, from 1,500 $\mathrm{ft}^{2}\left(139 \mathrm{~m}^{2}\right)$ in 1970 to 2,300 $\mathrm{ft}^{2}\left(214 \mathrm{~m}^{2}\right)$ in 2005 . The two-person household in a large home has become more common, as has central air conditioning: $23 \%$ of households had central air conditioning in 1978 that figure rose to $55 \%$ by 2001. Also, miscellaneous electric end-uses in households since 2000 has been rapidly expanding, largely offsetting efficiency gains in the conventional end-uses of heating, cooling and water heating.

Recent electricity shortages in California, growing U.S. dependence on foreign energy supplies with oil prices over $\$ 130$ per barrel, and the greatly expanding threat of global warming underscore the critical need to address the efficiency of residential energy systems. Since the twin energy crisis of the 1970s, first passive solar, then superinsulation and now zero energy homes have provided increasingly refined means to create a new generation of very low energy housing.

\section{History of Low Energy Residential Buildings}

Interest in reducing energy use in buildings began in the U.S. just before World War II with work at the Massachusetts Institute of Technology on solar heated structures. This lead to the construction of four successive research structures ending with the M.I.T. Solar House IV built in 1958-1959 with $60 \mathrm{~m}^{2}$ of active solar collectors which took care of $57 \%$ of measured space and domestic water heating in 1960-61 [2]. Similar work was done on solar air collector systems by Löf during the same period in Denver, but with less attractive savings [3].

With the twin energy crises in the 1970s, a flurry of activity developed means to reduce energy use in U.S. homes. Contrary to the complication and expense of active solar heating approaches as seen in the MIT and Colorado houses, of the initial activity was to utilize passive solar heating for buildings. Passive solar design aimed to use insulated southoriented glazing systems with direct gain, indirect gain (e.g. Trombe walls) and attached sunspace features. All configurations featured interior thermal mass to maintain interior thermal comfort while reducing the requirement for active heating and cooling systems [4]. The added cost of passive solar design with appropriate insulation was estimated in 1984 at approximately $\$ 50-\$ 150 / \mathrm{m}^{2}$. A compendium of seventy monitored passive solar homes reported an average 70\% savings in measured auxiliary space heating [5]. However, many aggressively glazed passive solar homes suffered summertime over heating and often required night-insulation for windows unless wide temperature swings in cold climates could be tolerated. Moreover, gradually within this research, researchers deduced that reducing building cooling and heating needs though energy conservation and balancing this with solar elements could achieve the lowest energy use at lower incremental cost [6]. In cold and cloudy climates it was also realized that substantially better insulated buildings could achieve much lower energy use than conventionally insulated structures [7]. This led to the advent of superinsulated homes. ${ }^{1}$

\footnotetext{
1 The term "superinsulation" was coined by Wayne Schick at the University of Illinois at Urbana-Champaign who was part of the team simulating the performance of the Lo-Cal house.
} 
In 1976 a computer simulation team at the Small Homes Council at University of Illinois Urbana that developed a design called the Lo-Cal house, evaluated using the climate of Madison, Wisconsin [8]. The house was never built, but its design features were highly influential. The key design facets of superinsulated homes were high insulation levels for ceiling, walls and floor (typically R-60, R-30 and R-20 or greater), very tight air construction and sun-tempering, with most of glass located on the south side of the building. Ventilation was provided by an air to air heat exchanger and target auxiliary design heat loads were a fraction of the size of ordinary furnaces.

In 1977, sponsored by the National Research Council of Canada, the cube-shaped Saskatchewan House was built in Regina, Saskatchewan. With an air to air heat exchanger for ventilation and no furnace installed, it was the first house to publicly demonstrate the value of superinsulation. The Saskatchewan House had an incremental cost of approximately \$6,000 in 1982. In 1979, the Leger Superinsulated House was built in East Pepperell, Massachusetts with an annual natural gas heating cost of only \$50 [9]. It had a more conventional appearance than the Saskatchewan House and widely influenced builders [10]. In 1984, three $223 \mathrm{~m}^{2}$ superinsulated homes built in Great Falls, Montana were extensively monitored. Even in a climate with 7,600 heating degree days, measured average resistance electricity use was only about $4,500 \mathrm{kWh}$ or $20 \mathrm{kWh} / \mathrm{m}^{2}$ [11].

A number of superinsulated houses were built over the next few years, but interest subsided as energy prices dropped in the 1980s. One weak point of the technology concerned the great attention to detail required for airtight construction and also the over-ventilation of some schemes using heat recovery ventilators. Within both the passive solar homes movement and that for superinsulation there remained the key issue that while heating energy use was reduced, cooling, water heating and the plethora of other home energy end uses were not addressed.

\section{$\underline{\text { Zero Energy Homes }}$}

Throughout the late 1980s, the cost of solid state solar electricity production through photovoltaics declined in price such that the possibility of using the solar resource for house-level distributed generation became increasingly feasible. In the early 1990s the Florida Solar Energy Center undertook a simulation exercise that looked to examine whether it was possible to aggressively reduce all home energy end-uses (cooling, heating, water heating, refrigerators, lighting and appliances) such that with photovoltaic electricity it might be possible to realize a annual zero net energy load [12]. Called the "Minimum Electricity Building," the exercise estimated that it might be possible to reduce total electrical load in a hot climate by two-thirds and heating and cooling by up to $80 \%$.

To evaluate the real-world potential, two highly-instrumented homes were built in Lakeland, Florida in 1998 - both with the same floor plan and constructed by the same builder. One of these was of conventional construction and served as the project control. The experimental building, called "PVRES," included all the features anticipated in the 
simulation exercise (Figure 1). The goal was to determine the extent to which advanced energy efficiency technologies can reduce the demand for electricity in Florida homes. Features included interior duct system with a high efficiency heat pump, better wall insulation, a white reflective roof system, solar water heating and efficient interior appliances and lighting. Over one year, the PVRES home used 6,960 kWh of electricity and had a PV system production of 5,180 kWh. For the same year, the Control used 22,600 $\mathrm{kWh}$. The measured a yearly energy savings due to the differences in the energy efficiency of the two homes of 70\%. Adding in the PV system production showed the PVRES house's net energy use (electricity from the utility) for the entire year was only $1,780 \mathrm{kWh}-\mathrm{a}$ reduction in energy use of $92 \%$ relative to the control.
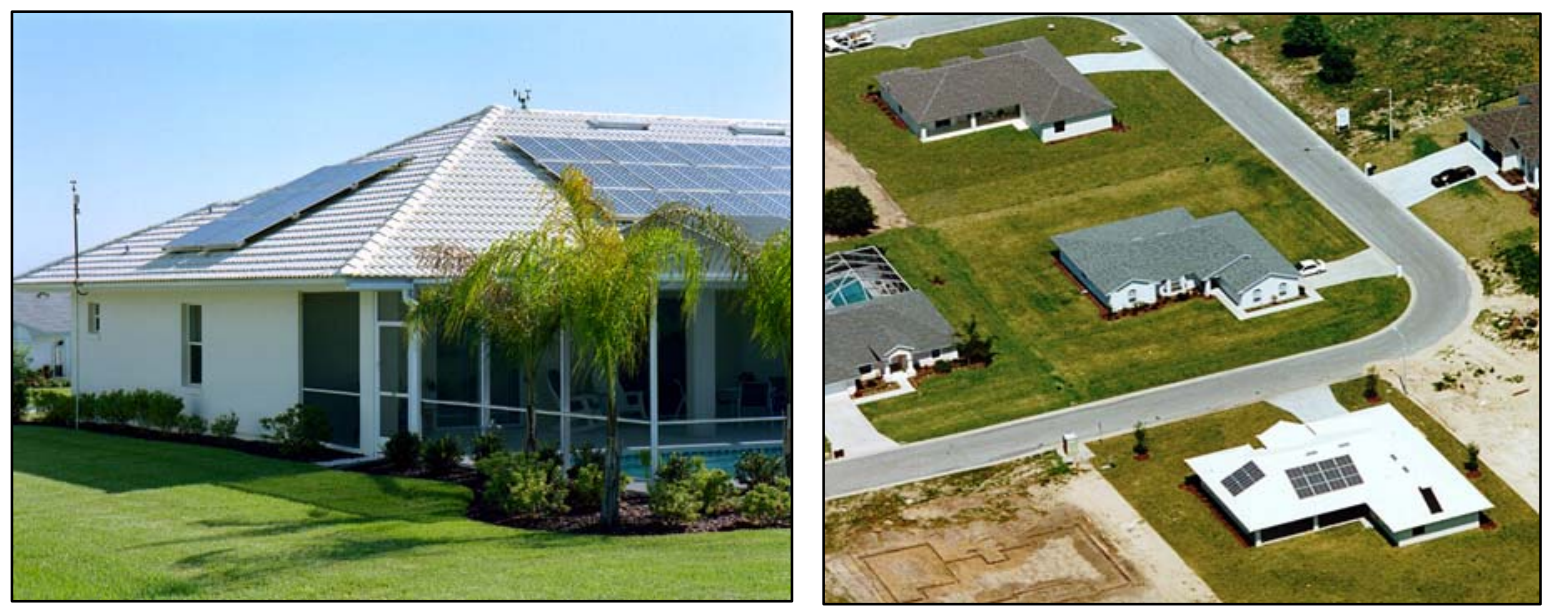

Figure 1. Lakeland Zero Energy Home (PVRES), view from SW and aerial view.

Moreover, the project showed that virtually zero net utility peak coincident demand was possible. As shown in Figure 2, the summer peak demand of all net end-uses in the occupied ZEH was above and below zero on the hottest summer day while air conditioning alone was $4.7 \mathrm{~kW}$ in the control home. 

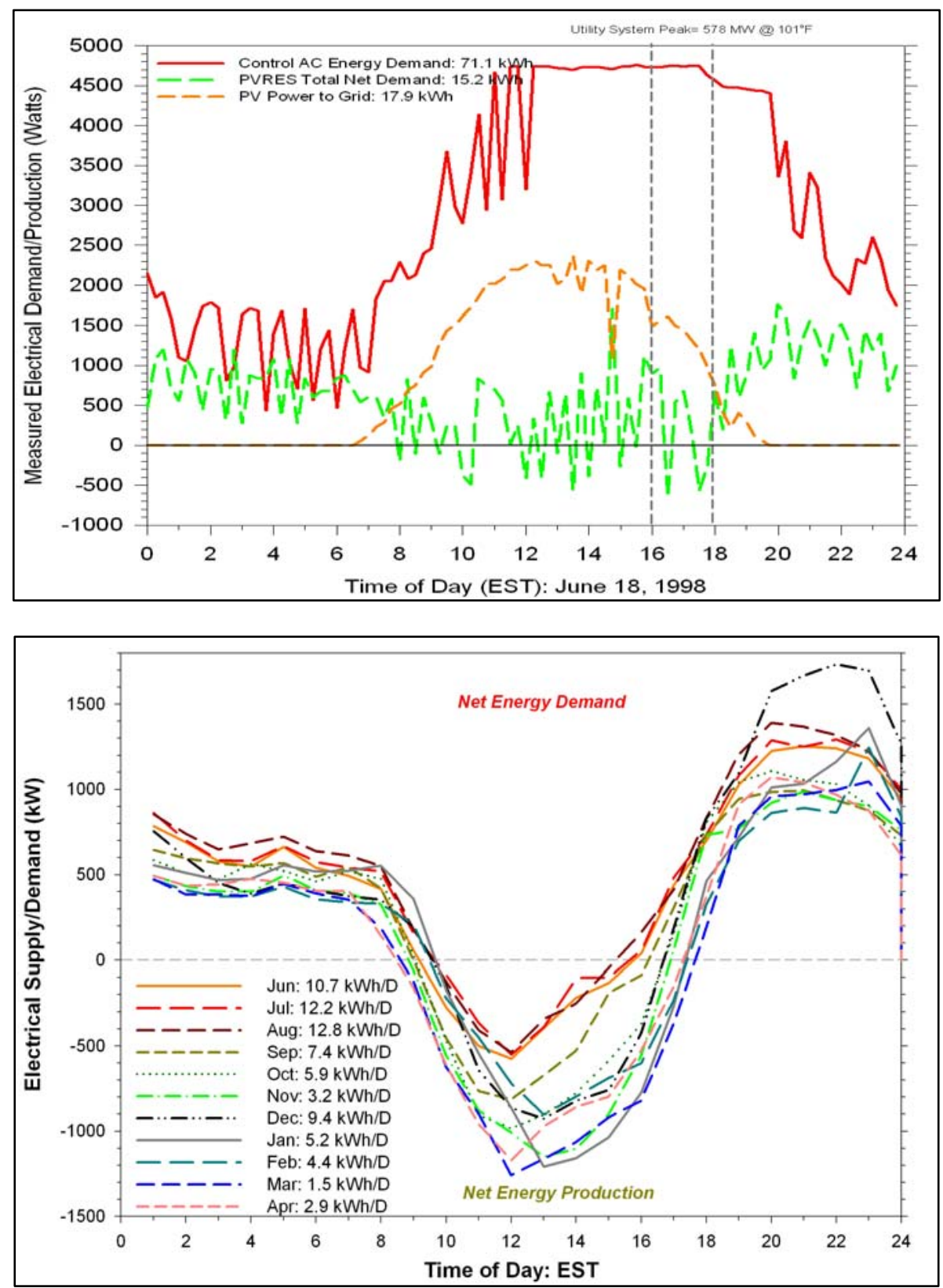

Figure 2. Upper plot - Net electrical demand of control, solar PV output and PVRES house on summer peak day. Lower plot - Long-term Lakeland electric demand by month

So successful was the project that it became the flagship for a new program for the U.S. Department of Energy: Zero Energy Homes. Within the concept, a combination of active and passive solar features with superinsulation and high efficiency appliances and overall load minimization is used with solar power generation to effectively lower annually net energy requirements to zero. Since the original zero energy project there have been many noteworthy zero energy homes constructed, some exceeding the performance of the original. Below we summarize some noteworthy projects. 
In Washington D.C. in 2001, a 2,800 square foot $\left(268 \mathrm{~m}^{2}\right)$ modular ZEH called the "Solar Patriot" or Hathaway home [13] was created to demonstrate potentials in a mixed climate. The home featured better insulated walls and foundation with low-e windows and high efficiency appliances and lighting throughout. An advanced geothermal heat pump was installed to further lower space conditioning loads with an evacuated tube solar water heating system. A $6 \mathrm{~kW}$ PV system was installed with the objective of reaching zero energy on an annual basis. The performance of the all-electric home was monitored in considerable detail. Total measured electricity consumption in 2002 was 10,585 $\mathrm{kWh}$ against the 7,510 $\mathrm{kWh}$ produced by the PV system. Although short of zero energy, the detailed monitoring of the home produced a wealth of information about the technologies and methods needed to achieve zero energy. For instance, it was determined that greater investments in efficiency than actually installed were likely warranted to further reduce space heating needs. Also, "other" energy use from home electronics and other plug loads were fully $23 \%$ of the energy use in the house. Figure 3 shows the measured consumption of various end-uses in the house versus the PV energy produced. Annual net energy consumption was only 3,075 $\mathrm{kWh}\left(11.8 \mathrm{kWh} / \mathrm{m}^{2}\right)$. Incremental cost for the construction was approximately $\$ 20,000$ for efficiency and HVAC improvements with another $\$ 39,000$ for the PV and $\$ 7,000$ for the solar water heating system. 

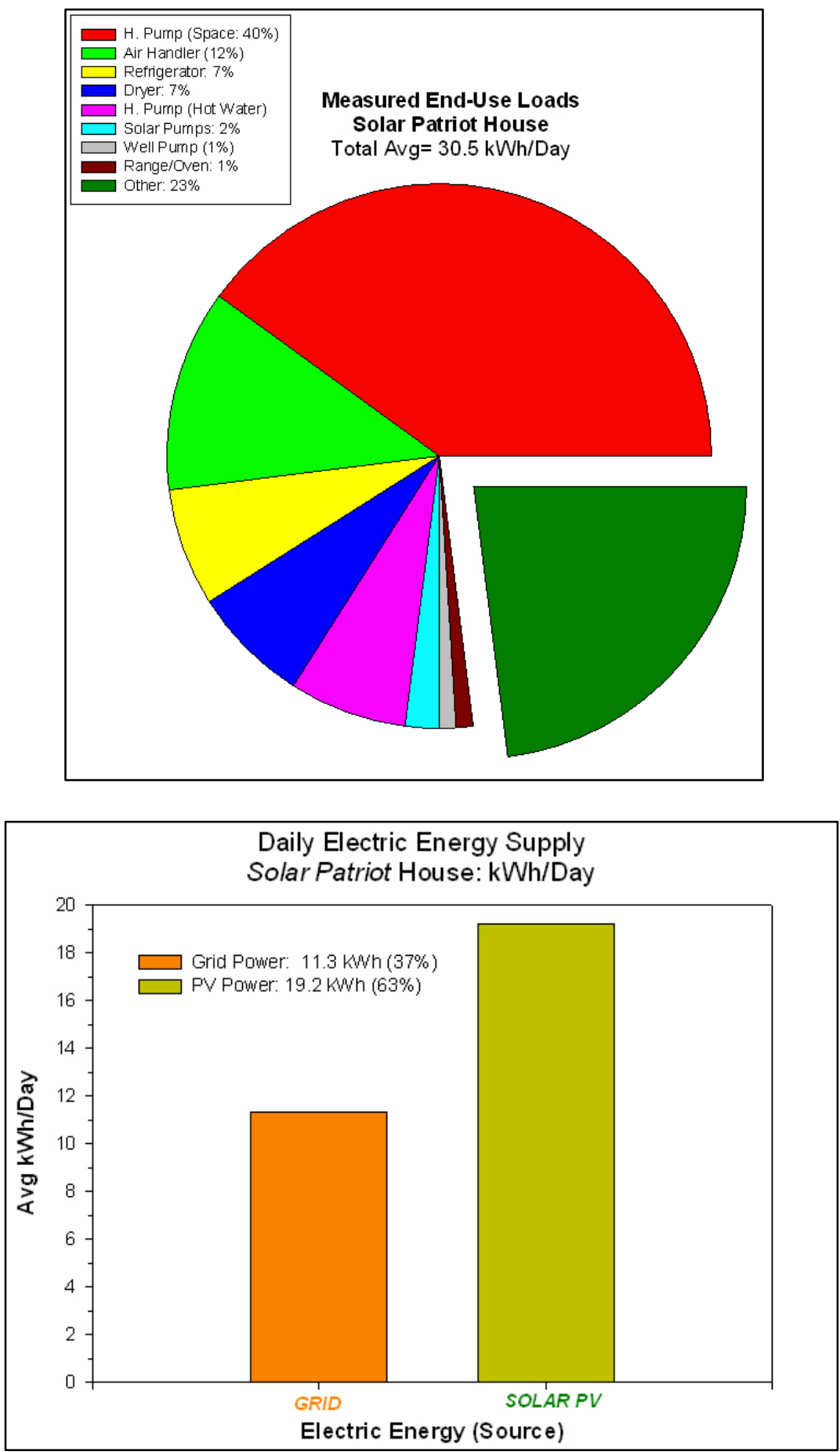

Figure 3. Monitored annual performance of "Solar Patriot" house in 2003 showing end-use consumption and net energy purchased from the grid.

In Livermore, California a 3,079 $\mathrm{ft}^{2}\left(286 \mathrm{~m}^{2}\right) \mathrm{ZEH}$ was designed by Davis Energy Group and built by Centex Corp in 2002 [14]. The home featured fairly high levels of insulation in a moderate climate, but included an innovative night cooling system (NightBreeze) using 
outside air introduced by the duct system, high performance windows with window shading, and attic radiant barrier, extensive use of tile with perimeter insulation and highly efficient appliances and lighting. Heating was provided by a hydronic loop using a tankless gas water heater. Cooling as provided by the NightBreeze with compressor cooling backup. The home also included a dynamic energy feedback system that allowed occupants to see how much energy their home was using against the energy being produced by the PV system. Performance of the house has been very good. In 2004, the $3.6 \mathrm{~kW}$ PV system produced more electricity $(4,890 \mathrm{kWh})$ than the house used $(4,380 \mathrm{kWh})$ so that net electricity consumption was negative: $-510 \mathrm{kWh}$. Very little compressor cooling was ever needed even in the hot conditions near California's Central Valley. In Figure 4 each point on the lines represents the average 15-minute electrical demand by time of day for 2004.

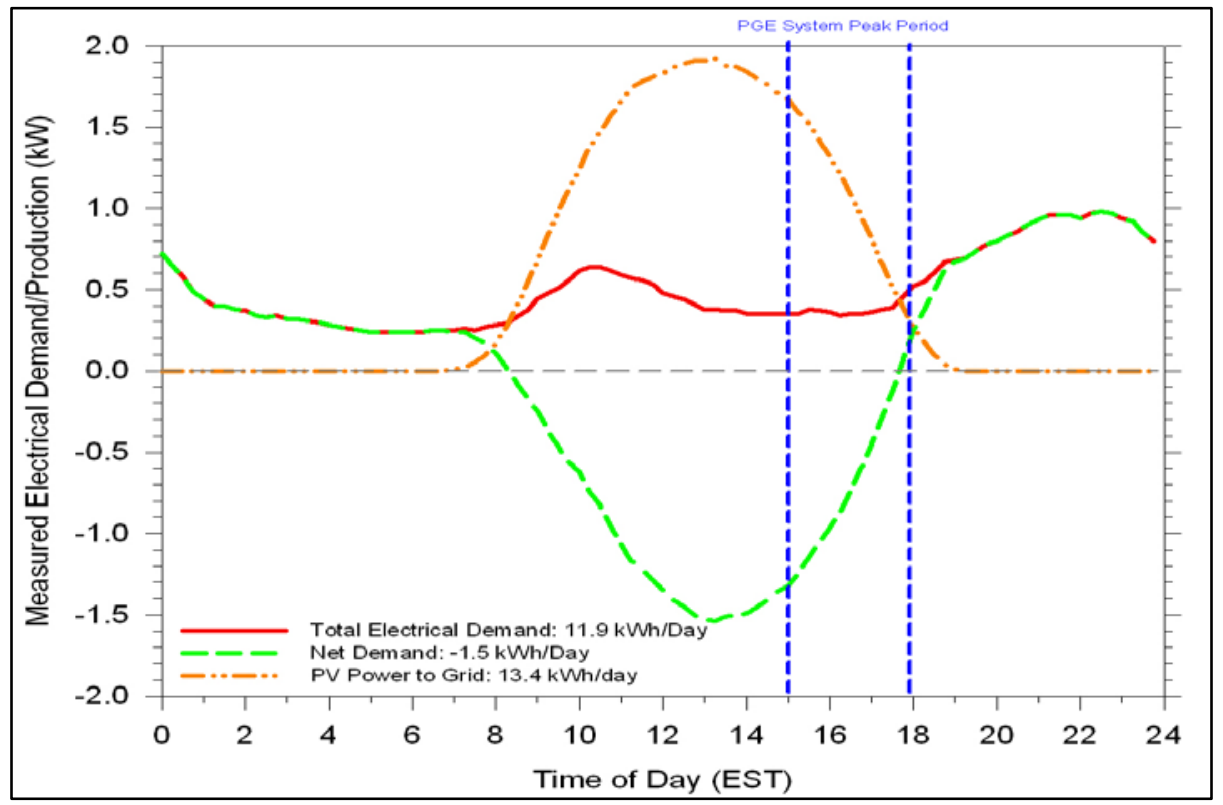

Figure 4. Long-term performance of Livermore ZEH 2003-2004 showing total, solar and net end-use demand averaged over a 24-hour period. Utility peak is shown on the plot as vertical lines.

However, natural gas consumption totaled 699 therms a year - likely due to excess heat loss in a hot water circulation loop. With that accounted for annual energy consumption equivalent was only 19,971 kWh or $70.6 \mathrm{kWh} / \mathrm{m}^{2}$. Incremental cost for the construction was approximately $\$ 26,000$ with another $\$ 40,000$ for the PV and solar water heating systems without California-specific rebates.

In Lenoir City, Tennessee, Oak Ridge National Laboratories has constructed five successively more advanced small near zero energy homes from 2002 - 2005 within a Habitat for Humanity development [15]. The project has been more impressive in that it has been done with small, affordable homes done while steadily improving performance, reducing costs and all the while evaluating a variety of efficient building methods and technologies such as: 
- Heat Pump Water heater linked to the Refrigerator for heat recovery

- Unvented Crawl space controlled by the thermostat for supplemental space cooling and dehumidification in the summer and serve as a radon mitigator in the heating mode

- Ground Source Heat Pumps using foundation heat recovery

- Structural Insulated Panels throughout

- Interior duct system within the insulated envelope

- High performance windows, efficient appliances

- Grey water waste heat recovery system

The first home built in 2002 had a net energy input after solar production of $84 \mathrm{kWh} / \mathrm{m}^{2}$ at an incremental costs of $\$ 54,000$ whereas the $5^{\text {th }}$ home constructed in 2005 had dropped net consumption to $33.9 \mathrm{kWh} / \mathrm{m}^{2}$ while reducing added costs to $\$ 48,000$.

In 2003, an innovative hot-climate design ZEH was built at Armory Park del Sol in Tucson, Arizona by John Wesley Miller. The all-electric 1,720 square foot home featured good insulation, solar control windows, a reflective roof and interior ducts with a high efficiency cooling system. One unique feature was the use of $120 \mathrm{ft}^{2}$ of flat plate solar collectors with 220 gallons (852 L) of storage that was to be used both for water and space heating. Measured performance over 2005 was quite good, although the solar thermal system fell short of expectations. Total electricity consumption was 8,786 kWh and the $4.2 \mathrm{~kW} \mathrm{PV}$ system produced 7,207 kWh in Tucson's sunny climate. Figure 5 summarizes performance measured over a second year of monitoring. Net consumption was only $1,578 \mathrm{kWh}$ for the year or $9.9 \mathrm{kWh} / \mathrm{m} 2$. The total cost of the system was $\$ 46,100$ of which $\$ 34,000$ was for the PV and solar water heating system.

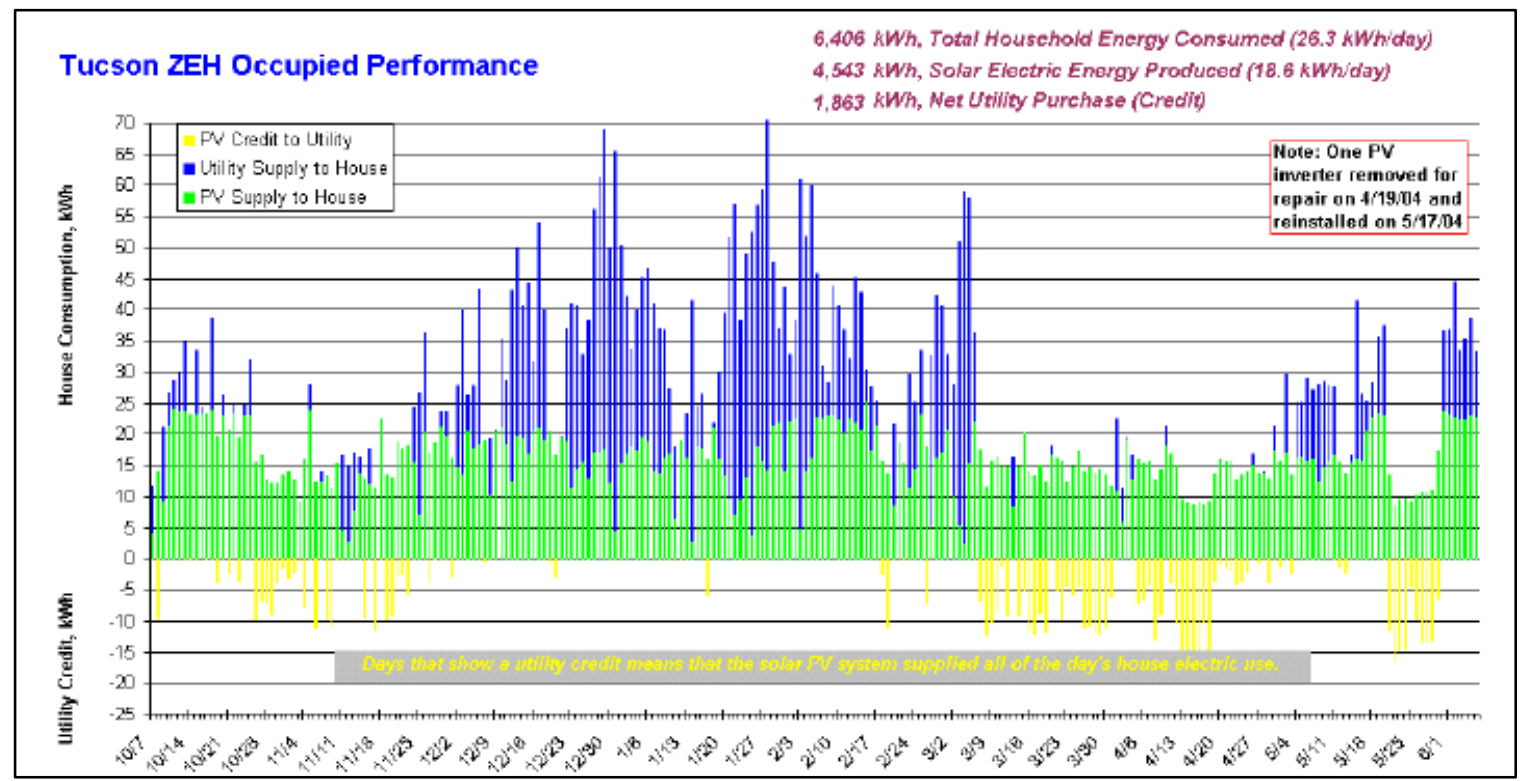

Figure 5. Measured performance of Armory Park del Sol showing PV electricity supplied to the home, PV sell back to the utility and utility supply to the home. 
Perhaps the most impressive recent ZEH project has been a small 1,280 square foot (119 $\mathrm{m}^{2}$ ) Habitat for Humanity home in Wheat Ridge, Colorado, as conceived by the National Renewable Energy Laboratory (NREL) [16]. The small home was superinsulated with R-60 ceiling, R-40 double stud walls and R-30 floor insulation (Figure 6). Ventilation is provided by a small heat recovery ventilator. Very high performance low-e solar glass with argon fill and a U-factor of 0.2 was used for the east, west and north faces with a higher transmission U-factor 0.3 glass used for the south exposure. The home used a $9 \mathrm{~m}^{2}$ solar collector with 757 liters of storage, backed up by a tankless gas water heater. The home was mated with a $4 \mathrm{~kW}$ roof-top PV system.

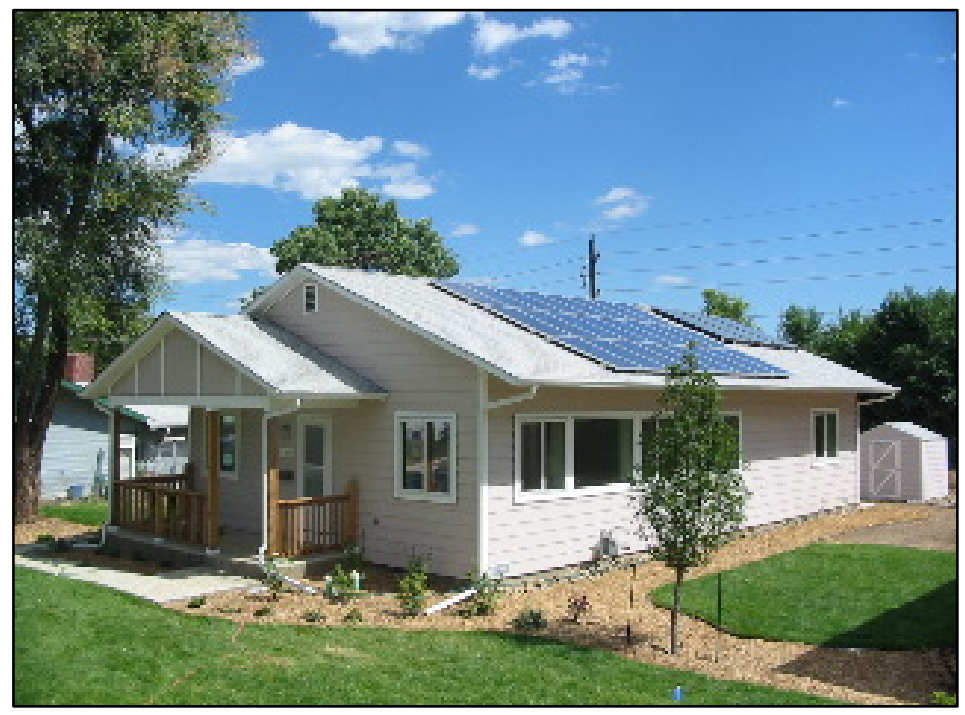

Figure 6. Habitat for Humanity Wheat Ridge ZEH.

During a year of data collection stretching from April 2005 to the end of March 2007, the PV system produced 1,542 kWh more than the electricity used in the home even though blizzards reducing PV output were experienced in January 2007.

It is interesting to note that some $60 \%$ of the electricity use in the home was for nonappliance, non-lighting miscellaneous electric loads. Only 57 therms of natural gas were used during this period. The excess electricity produced on site helped displace the natural gas use on a source energy basis. The net site energy requirement for al fuels of the home over the period was $1.1 \mathrm{kWh} / \mathrm{m}^{2}$ - very close to zero. The total incremental cost of the project was $\$ 42,500$ including $\$ 32,000$ spent for the PV system and $\$ 7,100$ for the solar water heating system. The incremental cost of the efficiency measures was only about $\$ 3,400$ due to savings in the elimination of a typical full scale furnace as would be found in a comparable building.

One of the most collectively compelling evaluations to date, Premier Gardens, is a community level project in Sacramento, California. This project saw 95 entry level homes constructed varying from 1,285 to 2248 square feet built with high levels of energy efficiency: R-38 ceiling insulation and R-13 to R-19 wall insulation, tank-less gas water 
heaters, high efficiency gas furnaces, tightly sealed ducts buried in the attic insulation, fluorescent lighting in all permanent fixtures. The Premier homes also included $2.2 \mathrm{~kW}$ of $\mathrm{PV}$ on each house. A unique element of the project was that across the street from the development was a similar housing project constructed by a similar builder without the higher efficiency measures or solar power. Samples of homes in both developments (average $169 \mathrm{~m}^{2}$ in size) were monitored by Sacramento Municipal Utilities District (SMUD). The measurement showed that the homes averaged 34\% lower gas consumption and $16 \%$ lower electricity use without solar power production being considered. With the PV included, the homes averaged 54\% lower electrical demand - particularly evident during summer peak periods as shown by the comparative data for July 15, 2005 (Figure 7). During the year of data collection, the homes in the nearby "control" development annually used 454 therms of gas and 7,770 kWh of electricity against 277 therms and 7,066 kWh for the Premier Homes. When solar electricity production is included (3,329 kWh), the consumption in the monitored sample averaged $70.1 \mathrm{kWh} / \mathrm{m}^{2}$. This was less than half the consumption of typical SMUD homes which used $144 \mathrm{kWh} / \mathrm{m}^{2}$. Incremental cost of the homes (not including the California PV buy-down) averaged \$18,836.

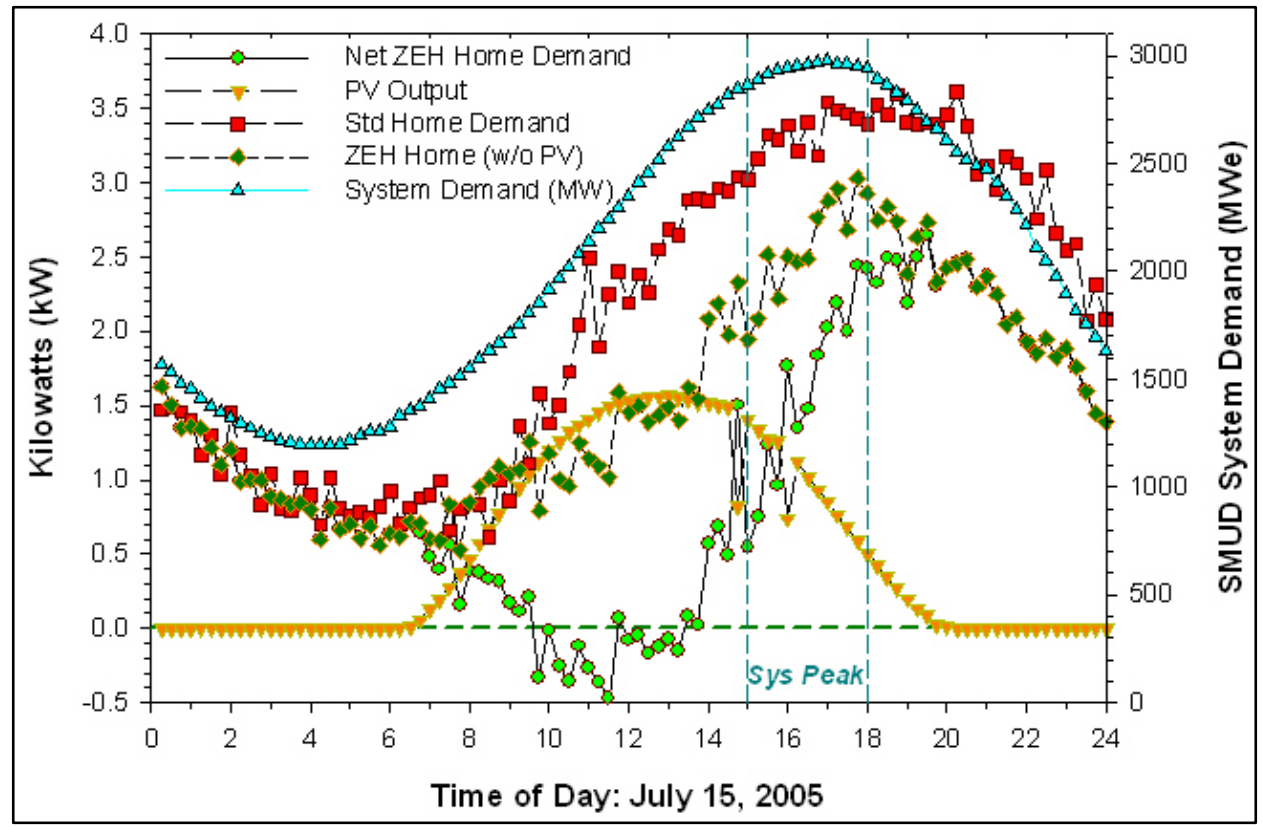

Figure 7. Average total, solar and net demand of non-ZEH and PrestigeGardens ZEH communities near Sacramento: peak summer day in 2005.

It must be emphasized that here we have highlighted a number of the more successful near zero energy home projects with monitored data. Given increasing interest, many more are currently under construction and/or monitoring.

\section{$\underline{\text { Smith-Klingenberg Passivhaus }}$}

The Passivhaus concept is a European design strategy for achieving very low energy buildings based on optimizing both first cost and operational costs. It was developed in 
Germany in the late-1980s by Dr. Bo Adamson and Dr. Wolfgang Feist, owing a large part of its origins to the superinsulation concept in the U.S. a few years before it [17]. However, there are important differences: the Passivhaus concept emphasizes the economic advantage of improving the building conditioned envelope to a point where a furnace becomes unnecessary, the need for eliminating all thermal bridging in construction, compact designs to minimize exterior surface area and extremely air tight construction with tiny heating systems integrated into the ventilation air distribution system and of designating specific performance targets along with software calculation of the levels required to reach those target. The specific targets are a space heating energy use no more than $15 \mathrm{kWh} / \mathrm{m}^{2}$ and a total primary energy consumption of $120 \mathrm{kWh} / \mathrm{m}^{2}$.

While many Passive houses have been constructed in Germany and Austria, the first one built in the U.S. was constructed in Urbana, IL in 2002-2003. The many construction features of the 1,200 square foot $\left(111 \mathrm{~m}^{2}\right)$ Smith/Klingenberg house are summarized in the attached summary (Figure 8).

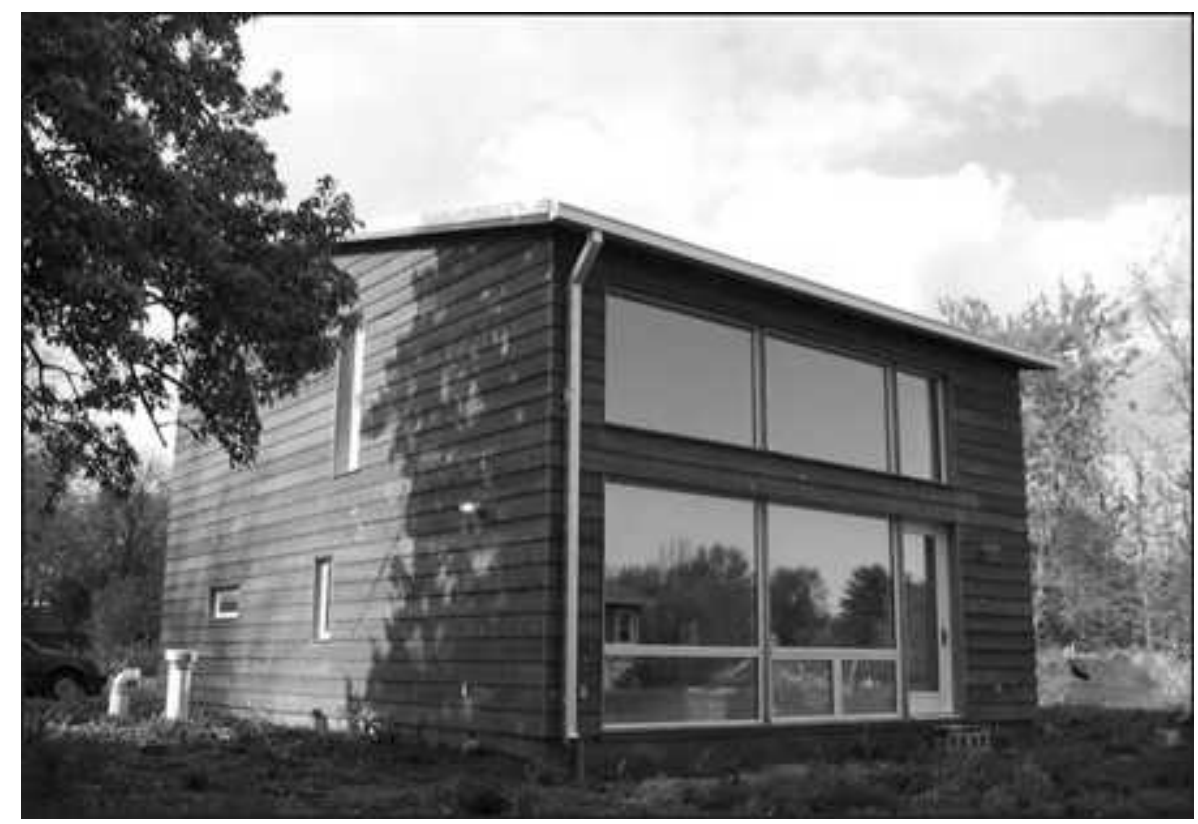

Figure 8. Smith-Klingenberg Passivhaus.

The annual total electricity consumption was 4,350 kWh (39 kWh/m² or $118 \mathrm{kWh} / \mathrm{m}^{2}$ of primary energy). Annual electricity consumption for heating was 1,065 kWh for the twelve month period between February 2005 and February 2006. On a unit area basis this translate to $10.7 \mathrm{kWh} / \mathrm{m}^{2}$ well below the limit of $15 \mathrm{kWh} / \mathrm{m}^{2}$ set forth in the Passive House Standard. The estimated incremental cost of the house was approximately $\$ 18,000$ or $\$ 162 / \mathrm{m}^{2}$. Since the performance of PV systems is highly predictable, it can be shown that with $3.8 \mathrm{~kW} \mathrm{PV}$ system near Chicago, Illinois, the Smith Passivhaus would become a Net Zero Energy Home as well. Within one of the plots, we estimated performance based on the added $\$ 32,000$ for such a PV system. 


\section{$\underline{\text { Summary of Zero Energy Homes and Passivhaus Conceptual Models }}$}

It can be readily seen that both the Zero Energy Home and Passivhaus concepts have some unique hazards within each approach. In general, both require very aggressive energy conservation measures to reach their goals. However, ZEH homes, given the ability to add on photovoltaics, can readily suffer under-investment in energy efficiency and over emphasis of renewable systems unless engineering simulations are run in the design process and best building envelope choices are made during construction. The author's personal experience with this process suggests that compromise within the building process is the greatest hazard.

On the other hand the Passivhaus concept risks overinvestment in conservation if a point is reached in the optimization process where adding solar electricity is a lower cost option than adding the next unit of insulation or air tightness. While the elimination of the heating system is a specific goal within that design process, that explicit step function in the cost optimization curve should be explored in a consistent fashion in the evaluation process.

Both approaches remain difficult and costly to achieve - particularly for standard building practice and standard appliances. This is precisely why the BEOpt software has been developed by the National Renewable Energy Laboratory within the Building America research process. As shown in Figure 9, it allows specific evaluation of each tradeoff in the locus of conservation options on the least cost curve [18].

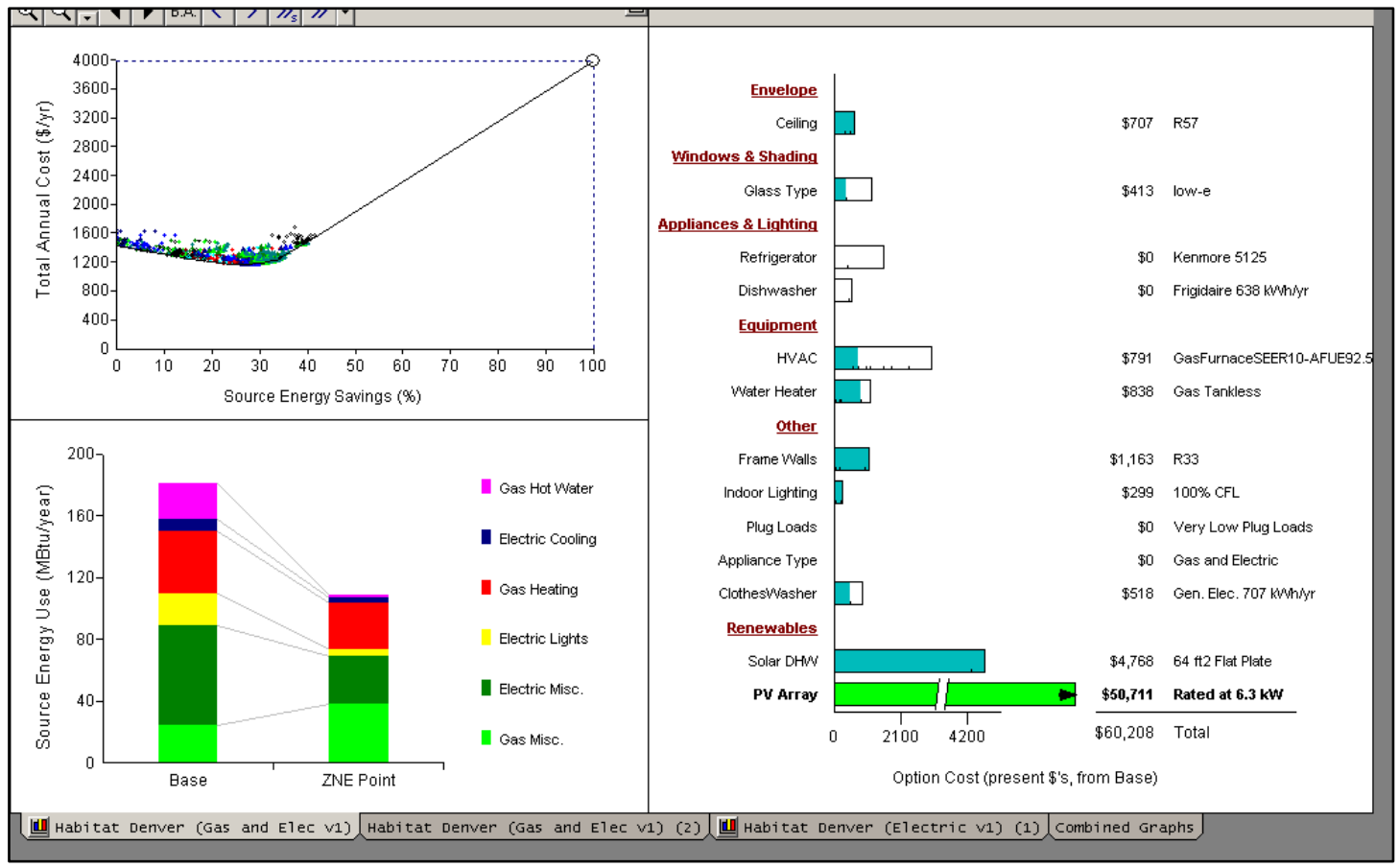

Figure 9.Original analysis of Wheat Ridge ZEH using BEOpt software to evaluate a wide parameter field of competing options. 
Based on the performance of the homes detailed here, the Passivhaus and Wheat Ridge efficiency levels are generally closer to the global optimum than that seen in many ZEH projects to date.

To show how the various low energy homes compare, we have prepared three data summary plots. ${ }^{2}$ Figure 10 shows how the cost of each project compares with the level of energy savings obtained from efficiency measures. The baseline homes are shown in red squares with savings shown from measured data (green triangles) for each of the projects. It is noted that costs are generally modest for efficiency measures in the homes - save for some of the more aggressive of the ORNL research projects.

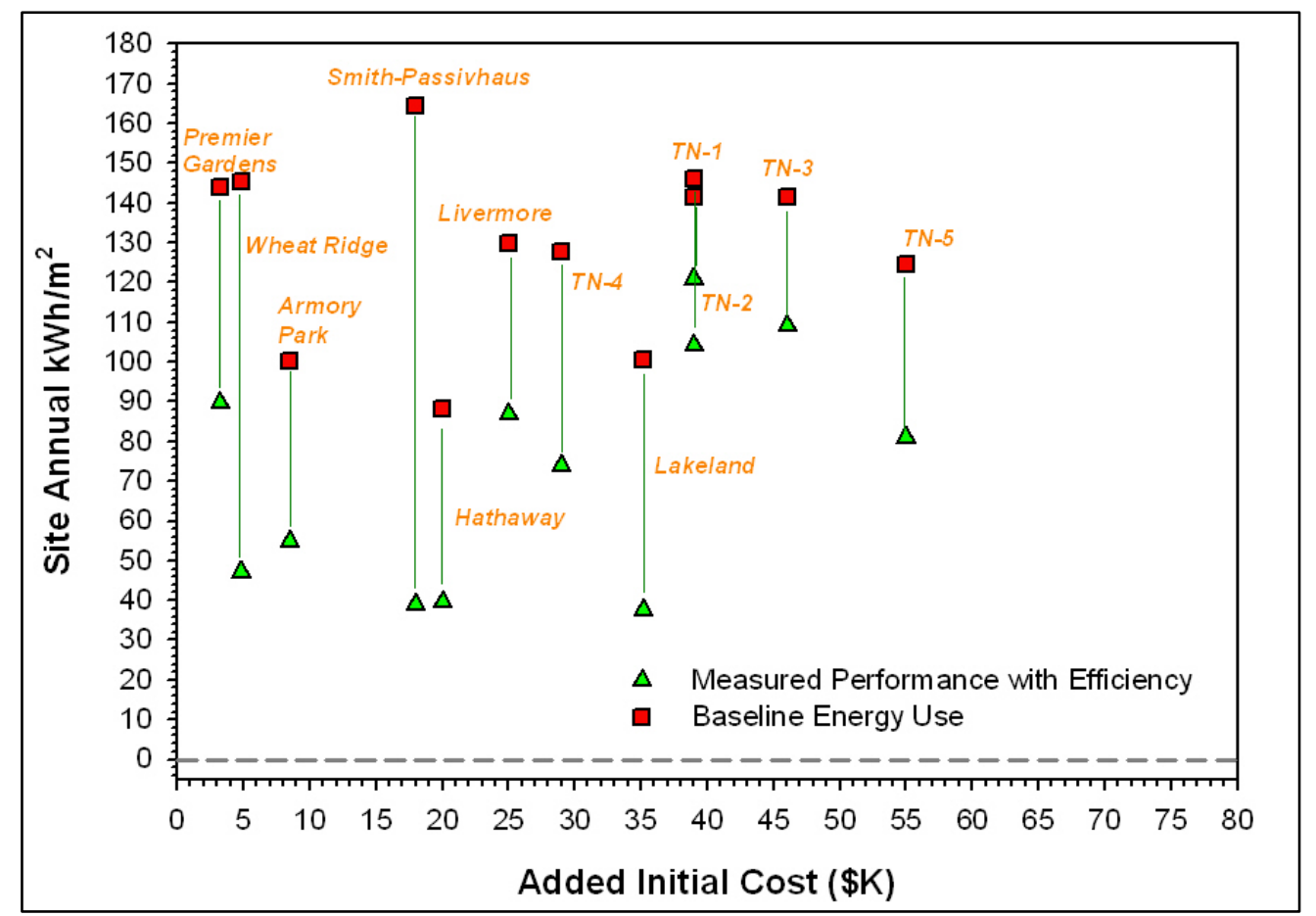

Figure 10. Performance of efficiency measures in low energy homes.

A second plot, Figure 11, shows similar data to that above with the costs and performance of the solar electric PV systems included. The PV costs are shown without rebates. The baseline building is shown by the red squares, the efficiency measures by the green triangles and the solar PV by the yellow circles. This data shows that the costs of PV adds another $\$ 20$ - $\$ 40 \mathrm{~K}$ to the project costs and with generally lower savings than those achieved from the efficiency measures.

\footnotetext{
${ }^{2}$ We caution that the data from the houses are from very different climates, differing sized homes and with varying degrees of added cost due to the research elements inherent in each.
} 


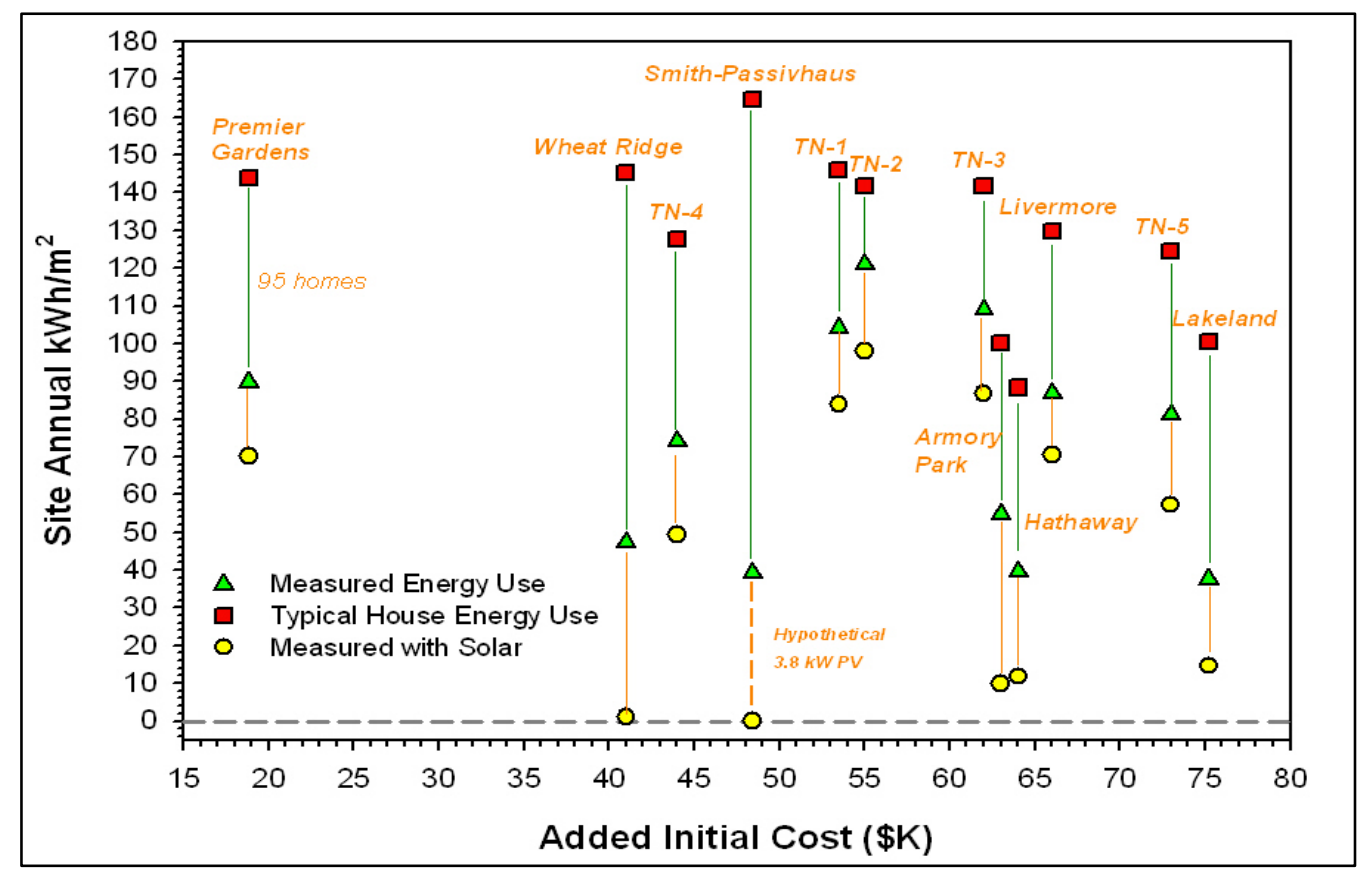

Figure 11. Summary of energy performance of twelve advanced Zero Energy Homes around the United States.

Figure 12 shows how the added costs for the efficiency and solar systems compare when the incremental costs for these elements are amortized at a 4\% real discount rate over 30 years (annualized capital recovery factor $=0.0578$ ). We then estimate the cost of conserved energy for the efficiency and PV sides of the achieved building performance. Most often the efficiency measures are more cost effective than the popular PV segments and hence remain a key prerequisite of any successful very low energy use programs. For instance, this argues for greater effort to improve energy efficiency within conventional Zero Energy Home designs such as the Hathaway House. On the other hand, over investment in efficiency or selection of more expersive options can mar potential economics. An example of this is the emphasis of more costly structurally insolated panels (SIPs) and ground source heat pumps in the ORNL ZEH projects versus the lower cost double-stud wall construction used in the NREL Habitat project. 


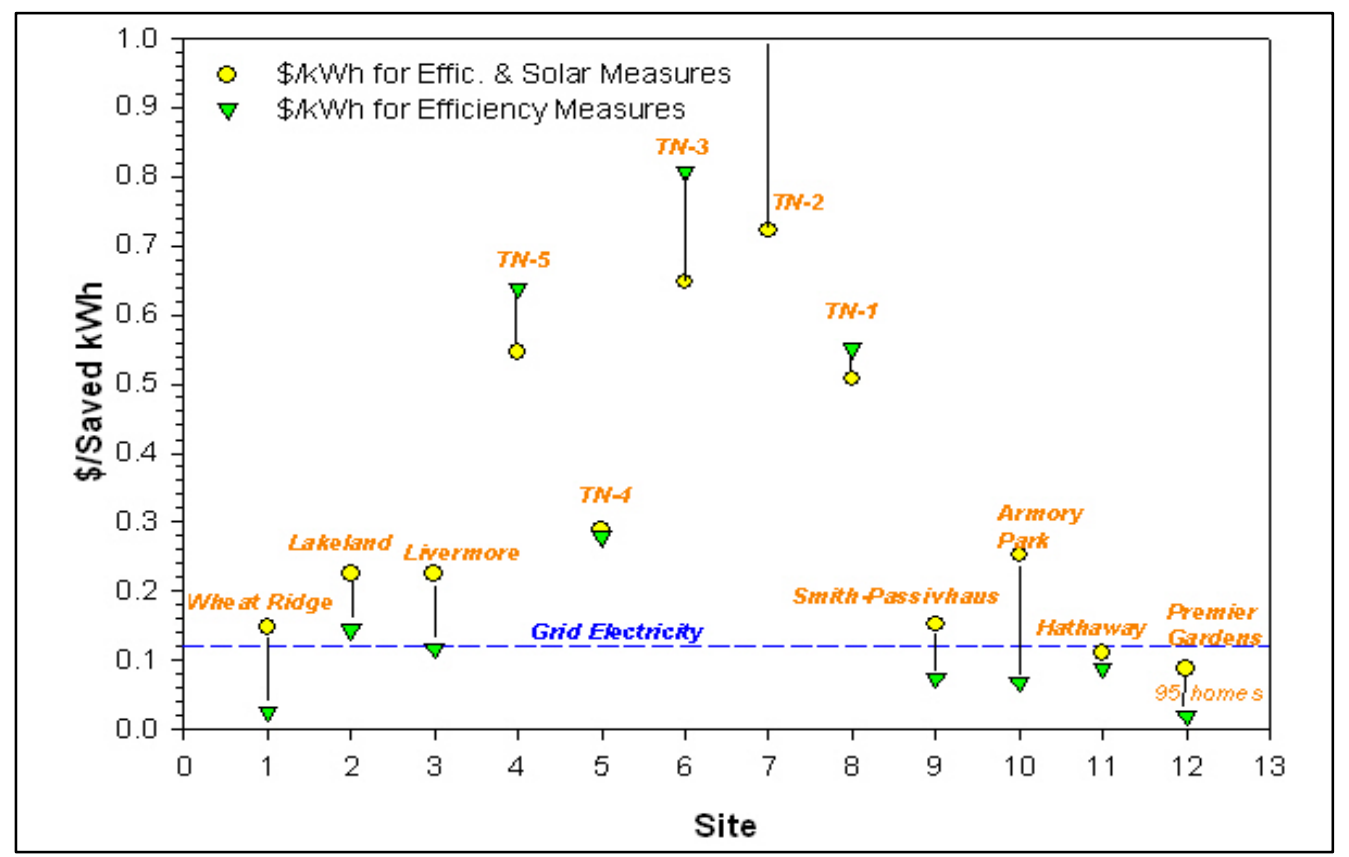

Figure 12. Cost of conserved energy for efficiency and solar elements in low energy homes.

\section{Community Scale Efforts}

Beginning in 2001, three other builders in California (Shea Homes, Clarum Homes and Grupe Homes) and one in Arizona (John Wesley Miller) have built entire communities of high performance homes with photovoltaic systems similar to the Premier Homes project. Bill analysis data for Shea Homes show 54\% annual energy savings on a whole house basis (for homes with the $2.4 \mathrm{~kW}$ PV system) compared to communities of adjacent homes [19]. Buyers of such near ZEH homes are also very happy with their utility bills. For instance, the average monthly utility bills for the John Wesley Miller Armory Park del Sol community of 97 homes in Tucson, AZ has been less than \$16/month.

One of the most significant findings is that all four California builders report that their near ZEH homes sell much faster than conventional ones - a highly desirable attribute for builders. Grupe Homes has provided recent data showing an estimated savings of \$13 million for their 144 home near ZEH community (Carsten Crossings) from the fact that the NZEH homes were are selling twice as quickly as the competition. Also, so successful has been the Premier Gardens project in California that Sacramento Municipal Utilities District has developed a utility program based on this model with over 4,000 such homes under contract with eight different builders.

\section{Claiming the Potential}

Based on thirty years of research effort, we already know much about how to reduce energy use in our homes. This was convincingly demonstrated in an early ZEH project in Lakeland, Florida where two houses were built, one standard and the other efficient with photovoltaics. We used off-the-shelf technologies and reduced measured energy cooling 
use by $75 \%$ and total energy use by $93 \%$ once the solar electricity was counted [20]. As seen in this summary, other such homes have been built, but surprisingly few given expressed public interest in reducing greenhouse gas emissions.

Economics is at least partly to blame for our torpid progress. Standard thinking often evokes a faulty time horizon for personal decisions with societal consequences. Since most may only live in a house for an average of seven years, unless a technology or innovation pays for itself in half that time, most tend to dismiss it [21]. Why should an investor pay for the benefits inherited by another person buying their home? The answer is, of course, that the person buying that home is ourselves. Another economic failure is the perceived lack of valuation of energy efficiency features in resale - a real estate valuation gap that may be remedied by an expanding data base of such homes in California. There is also another limitation of classical micro-economics: uncertainty is not properly accounted within a typical life-cycle cost approach. True, the sensitivity analysis and risk assessment techniques can be applied to its static framework, but these studies belong to the rarified world of academia [22]. Financial and energy planners don't want a Monte Carlo derived range of probabilities; they want a single answer. We demand that the complex estimation be made simple - simple enough where our assumptions may paint us in to a hopelessly inadequate position.

To place this in perspective, one need only recall the difficult progress on policy matters ranging from fuel efficiency standards for automobiles to SEER minimums for air conditioners where payback and lifecycle costs dominate the evaluation rather than the possibility that foreign oil dependence or peak electricity demand could become crushing problems. Moreover, excess $\mathrm{CO}_{2}$ production and global climatic damage might be exacting a planet-level illustration of Garret Hardin's “Tragedy of the Commons [23].”

Economics forever looks at the future as if it is a reflection of the past - a flawed myopia. Yet, the energy picture will constantly change such that targeting based on present position is prone to underachieve what might be vital. Put another way, the economic downside of making our homes more efficient than economically justified in the future is much less catastrophic than a world where energy prices suddenly rise and we find ourselves still housed in buildings that are too expensive to operate.

Recently, however, there have been encouraging signs. The Passivhaus movement in Europe along with the explosion in renewable energy power production there, are promising [24]. In the U.S, large-scale developments with near ZEH homes such as those seen in California illustrate both the potential and means for much more wide spread transformation towards advanced energy-efficient housing in the $21^{\text {st }}$ century.

\section{$\underline{\text { Summary }}$}

In general, the presented research data above would suggest that while genuine research challenges remain, very low energy use buildings can very readily be achieved in North America. In general, the greater cost effectiveness seen from energy efficiency measures in 
this evaluation indicates that greater investment in conservation should be a prerequisite to installation of solar water heating and solar electricity in Near Zero Energy Homes. The same data also would reveal a tendency towards underinvestment in energy efficiency relative to renewable energy in many previous projects and the need to re-emphasize the efficiency element.

Collective political will may be the more difficult issue than the research data to support the tasks. Very low energy buildings, both new and existing, are fully within our grasp if society deems their achievement a national priority.

\section{Acknowledgements}

This work is a result of a request from Arthur Rosenfeld - Commissioner, California Energy Commission and member of the National Academy of Sciences panel. This draft was put together with considerable cooperation from others, especially from my colleague, Dr. Subrato Chandra at the Florida Solar Energy Center. I further appreciate help from Paul Norton, National Renewable Energy Laboratory, Katrin Klingenberg, E-Co Lab; David Springer, Davis Energy Group, Jeff Christian, Oak Ridge National Laboratories, Mike Keesee, SMUD, Rob Hammon, CONSOL, Joseph Wiehagen, NAHB, Lew Pratsch, U.S. Department of Energy and Philip Fairey of the Florida Solar Energy Center.

This work was performed as part of the Building America Industrialized Housing Partnership under sponsorship of the U.S. DOE (Cooperative Agreement \#DE-FC2606NT42767). The views expressed in this report are solely of the authors and do not imply endorsement of the Florida Solar Energy Center or the U.S. Department of Energy.

\section{References}

[1] See "Direct Use and Retail Sales of Electricity to Ultimate Customers by Sector," http://www.eia.doe.gov/cneaf/electricity/epa/epat7p2.html; DOE, Residential Energy Consumption in 2001, DOE, Energy Information Administration, Washington D.C, Weblink:

ftp://ftp.eia.doe.gov/pub/consumption/residential/2001hc_tables/spaceheat_household2001. pdf. In $55 \%$ of U.S. homes, natural gas is the primary heating fuel (electricity $=29 \%$; fuel oil $=7 \%$; LPG $=5 \%$ )

[2] C. D. Engebretson, 1964, "The Use of Solar Energy for Space Heating- M.I.T. Solar House IV,” Proceedings of the UN Conference on New Sources of Energy, 5, 1959.

[3] G. O. Löf, M. M. El-Wakil and J. P. Chiou, 1963. "Residential Heating with Solar Heated Air- The Colorado Solar House,” ASHRAE Tranactions, 77, October 1963. 
[4] J. D. Balcomb, 1984, "Passive Solar Research and Practice,” Energy and Buildings 7, pp. 281-295.

[5] SERI, 1984. Passive Solar Performance Summary of 1982-1983 Class B Results, SERI/SP-271-2362, Golden, CO.

[6] J. D. Balcomb, “Conservation and Solar: Working Together," Proceedings of the $5^{\text {th }}$ National Passive Solar Conference, Amherst, MA, 1980. Also, Balcomb J. D., 1986, “Conservation and Solar Guidelines,” Passive Solar Journal, 3(3), pp. 221-248.

[7] L. Palmiter, "Optimum Conservation for Northwest Homes," Proceedings of the $6^{\text {th }}$ National Passive Solar Conference, Portland, OR, 1981.

[8] W.L. Shick, R.A. Jones, W.S. Harris and S. Konzo, 1979. Technical Note 14: Details and Engineering Analysis of the Illinois Lo-Cal House, Urbana, IL, University of IL.

[9] Shurcliff, William A., Superinsulated houses: A Survey of Principles and Practice, Brick House Pub. Co, 1981

[10] Nisson, J. D. Ned; and Gautam Dutt, The Superinsulated Home Book, John Wiley \& Sons, NY, 1985

[11] L. Palmiter, and J. Hanford, "Measured Performance of Three Superinsulated Homes in Montana," Conservation in Buildings: A Northwest Perspective, National Center for Appropriate Technology, Butte, MT,

[12] Parker, D., Dunlop, J., "Solar Photovoltaic Air Conditioning of Residential Buildings," Proceedings of the 1994 Summer Study on Energy Efficiency in Buildings, August 1994. The development of the building simulation, that allowed simultaneous evaluation of hourly total energy needs as well as PV system performance eventually became the EnergyGauge USA simulation software, now widely used to evaluate zero energy home designs.

[13] P. Norton, E. Hancock, G. Barker, and P. Reeves, The Hathaway "Solar Patriot" House: A case Study in Efficiency and Renewable Energy, U.S. Department of Energy, NREL/TP-550-37731, May 2005.

[14] "First Zero Energy Home Goes Up in California,” The Air Conditioning, Heating and Refrigeration News, 29 July 2002.

[15] J.E. Christian, D. Beal and P. Kerrigan, "Toward Simple Affordable Zero Energy Houses," Proceedings of the Thermal Performance of the Exterior Envelopes of Buildings IX, Clearwater, FL, December 2004. 
[16] Paul Norton and Craig Christiansen, 2006. “The Little House that Could,” Home Energy, November/December, 2006. Also, P. Norton and C. Christiansen, A Cold Climate Case Study for Affordable Zero Energy Homes, NREL- CP-550-39678, National Renewable Energy Laboratory, Boulder, CO.

[17] Wolfgang Feist, Passivhäuser in Mitteleuropa. Doctoral Dissertation, Darmstadt, 1992. Krapmeier, Helmut and Drössler, Eckart. 2001. CEPHEUS—Living Comfort without Heating. Vienna: Springer-Verlag.

[18] C. Christiansen, S. Horowitz, R. Anderson and S. Barker, BEOpt: Software for Identifying Optimal Building Designs on the Path to Zero Net Energy, NREL CP-05503733, Proceedings of the ISES Solar World Energy Congress, Orlando, FL, 2005.

[19] Michael C. Baechler, Theresa Gilbride, Kathi Ruiz, Heidi Steward and Pat M. Love, High-Performance Home Technologies: Solar Thermal \& Photovoltaic Systems, prepared for Building America, U.S. Department of Energy, NREL TP-550-41085, June 2007.

[20] D.S. Parker, J.P. Dunlop, S.F. Barkaszi, J.R. Sherwin, M.T. Anello and J.K. Sonne, 2000. "Towards Zero Energy Demand: Evaluation of Super Efficient Building Technology with Photovoltaic Power for New Residential Housing,” Proceedings of the 2000 ACEEE Summer Study on Energy Efficiency in Buildings, American Council for an Energy Efficient Economy, Washington D.C., Vol. 1, p. 207.

[21] This notion is supported by a seminal assessment by Hausman of MIT who showed that consumer purchase behavior of air conditioning systems indicated an implicit real discount rate of $26 \%$-- far out of keeping with opportunity costs of capital. The analysis argued for regulation of energy using appliances. Jerry A. Hausman, "Individual Discount Rates and the Purchase and Utilization of Energy-Using Durables,” Bell Journal of Economics, Vol. 10, No. 1, 1979.

[22] See "Risk Analysis and Decisions Under Uncertainty" in J.A. White, M.H. Agee and K.E. Case, Principles of Engineering Economic Analysis, John Wiley \& Sons, NY.

[23] Garrett Hardin, "The Tragedy of the Commons," Science, 162(1968):1243-1248.

[24] Jürgen Schnieders and Andreas Hermelink, "CEPHEUS Results: Measurements and Occupants' Satisfaction Provide Evidence for Passive Houses Being an Option for Sustainable Building, ” Energy Policy 34 (2006) pp. 151-171. 


\title{
Exemplary Low Energy House Performance Summaries
}

\author{
Site Designation: Lakeland Zero Energy Home \\ Location: Lakeland, FL \\ Contact: Danny Parker (Dparker@fsec.ucf.edu) \\ Year of Construction: 1998 \\ Conditioned Floor Area: 2,425 ft2 $\left(225 \mathrm{~m}^{2}\right)$ \\ Measured Annual Total kWh: (all end uses) 6,960 kWh; 19.1 kWh/Day \\ Measured Annual Natural Gas Therms: (All end uses) None \\ Other Energy Source Use: 54 gallons of propane used (5.16 x $106 \mathrm{Btu}$; or 1,511 kWh heat \\ equivalent) \\ Year of Measurement (12 month period) July 12001 - June 30, 2002 \\ Normalized Total Annual Energy Use: $37.6 \mathrm{kWh} / \mathrm{m}^{2}$ \\ Annual kWh Solar Electric Production: 5,180 kWh \\ Net Electricity Use: 1,780 kWh (4.9 kWh/Day) \\ Normalized Net Energy Use: $14.6 \mathrm{kWh} / \mathrm{m}^{2}$ \\ Primary Design Features (Energy Efficiency): highly reflective roofing, interior duct \\ system, low-e solar control windows, efficient lighting and appliances; high SEER heat \\ pump; exterior wall insulation \\ Primary Design Features (Renewable Energy): solar water heater; 4 kW PV system (2.7 \\ $\mathrm{kW}$ facing south; $1.3 \mathrm{~kW}$ facing west) \\ Estimated Incremental Cost of Construction: \$35,200 \\ Estimated Incremental Cost of any Solar Features: (include both solar hot water and PV): \\ $\$ 40,000$ \\ Other Project Comments: PV costs would be approximately 20\% lower ten years later; also \\ better cooling systems are now available and lower cost wall options. Control home of the \\ same size without features use 22,600 $\mathrm{kWh}$ for the same year $\left(100 \mathrm{kWh} / \mathrm{m}^{2}\right.$ and roughly \\ $300 \mathrm{kWh} / \mathrm{m}^{2}$ for primary energy consumption). \\ Project Weblink: \\ http://www.fsec.ucf.edu/en/research/buildings/zero_energy/lakeland/index.htm
}

\author{
Site Designation: Livermore ZEH \\ Location: Livermore, CA \\ Year of Construction/Renovation: 2002 \\ Conditioned Floor Area: $3080 \mathrm{ft} 2$ \\ Measured Annual Total kWh: (all end uses) 4367 kWh \\ Measured Annual Natural Gas Therms: (All end uses) 699 therms \\ Year of Measurement (12 month period) 2007 \\ Annual kWh Solar Electric Production: 4658 kWh \\ Primary Design Features (Energy Efficiency): \\ -R-10 slab edge insulation \\ $-2 \times 4$ walls with cellulose insulation \\ -R-38 ceiling insulation (cellulose)
}


-Radiant barrier roof sheathing

-House \& ducts tested for tightness (SLA 3, $<6 \%$ duct leakage)

$-5 / 8$ " drywall and 50\% hard surface floors (for mass)

-Low E2 windows ( 0.34 U \& SHGC)

-Exterior window shading (trellis) on east and south, deep patio on west

-Tankless water heater (0.82 EF) and on-demand hot water recirculation

-NightBreeze integrated ventilation cooling, heating \& AC (two variable

speed fan coils served by tankless water heater)

-SEER $13 \mathrm{~A} / \mathrm{C}$

Primary Design Features (Renewable Energy):

-3.6 kWdc Astropower modules, 3 inverters (3 strings)

$-48 \mathrm{ft} 2,80$ gal. solar water heater (closed loop, antifreeze), PV

powered brushless pump

Estimated Incremental Cost of Construction:

If Centex had been charged for the added components, incremental costs would likely have exceeded \$25,000. PV modules were provided and installed by AstroPower (currently GE). The solar water heater was donated and installed by Solahart, and Rinnai donated the tankless water heater.

Estimated Incremental Cost of Solar Features: (include both solar hot water and PV) These were donated. The solar water heater would likely have cost $\sim \$ 5,000$ and the PV system $\$ 18,000$ after rebates.

Other Project Comments: The house has been continuously monitored for over five years. The owners have yet to be charged for electricity usage. The house has been reported on in several reports.

Contact: David Springer, Davis Energy Group

Project Weblink: www.davisenergy.com, http://www.fsec.ucf.edu/en/research/buildings/zero_energy/livermore/

Site Designation: Hathaway Zero Energy Home

Location: Purcellville, VA (outside Washington DC)

Contact: Paul Norton (Paul_Norton@NREL.gov)

Year of Construction: 2001

Conditioned Floor Area: $2880 \mathrm{ft}^{2}\left(268 \mathrm{~m}^{2}\right)$ in two stories on unconditioned basement

Measured Annual Total kWh: (all end uses) 10,585 kWh; 20 kWh/Day

Measured Annual Natural Gas Therms: (All end uses) None

Other Energy Source Use: None

Year of Measurement (12 month period): January - December 2002

Normalized Total Annual Energy Use: $39.5 \mathrm{kWh} / \mathrm{m}^{2}$

Annual kWh Solar Electric Production: 7,410 kWh 
Net Electricity Use: 3175 kWh (8.7 kWh/Day)

Normalized Net Energy Use: $11.8 \mathrm{kWh} / \mathrm{m}^{2}$

Primary Design Features (Energy Efficiency): Ground source heat pump, R-38 attic insulation, R-19 walls + R5 sheathing, and interior duct system, High performance solar control low-e windows, efficient appliances, compact fluorescent lighting Primary Design Features (Renewable Energy): $6.0 \mathrm{~kW}$ PV system (facing south on 5/12 pitch roof), solar hot water with evacuated tube collectors, 80 gallon storage and geothermal heat pump auxiliary backup Estimated Incremental Cost of Construction: \$20,000 Estimated Incremental Cost of any Solar Features: (include both solar hot water and PV): PV cost $\sim \$ 39,000$ for PV, $\$ 7,000$ for solar hot water Project weblink: http://www.nrel.gov/docs/fy05osti/37731.pdf, http://www.ert.net/solarhome/chapters.htm

\title{
Site Designation: ZEH5-two-story $\left(2600 \mathrm{ft}^{2}\right)$ Zero Energy Home
}

Location: Lenoir City, TN

Contact: Jeff Christian (ChristianJE@ORNL.gov)

Year of Construction: 2005

Conditioned Floor Area: 2,632 $\mathrm{ft}^{2}\left(245 \mathrm{~m}^{2}\right)$

Measured Annual Total kWh: (all end uses) 10995 kWh; 30.1 kWh/Day

Measured Annual Natural Gas Therms: (All end uses) None

Other Energy Source Use: None

Year of Measurement (12 month period) Jan 12007 - Dec. 31, 2007

Normalized Total Annual Energy Use: $44.9 \mathrm{kWh} / \mathrm{m}^{2}$

Annual kWh Solar Electric Production: 2697 kWh

Net Electricity Use: 8298 kWh (22.7 kWh/Day)Normalized Net Energy Use: 33.9 kWh/m² Primary Design Features (Energy Efficiency): foundation geothermal heat pump system, ZEHcor wall, Structural Insulated Panel roof and above grade walls, air-tight construction, ASHRAE 62.2 mechanical ventilation compliant, reflective raised metal roofing, interior duct system, High performance windows, efficient lighting and appliances, exterior foundation wall insulation, walkout lower level Primary Design Features (Renewable Energy): solar water heater; 2.2 kW PV system (facing south on 4/12 pitch roof)

Estimated Incremental Cost of Construction: \$30,200

Estimated Incremental Cost of any Solar Features: (include both solar hot water and PV): $\$ 18,000$

Other Project Comments:

\author{
Site Designation: ZEH5-one-story $\left(1240 \mathrm{ft}^{2}\right)$ Zero Energy Home \\ Location: Lenoir City, TN \\ Contact: Jeff Christian (ChristianJE@ORNL.gov) \\ Year of Construction: 2005 \\ Conditioned Floor Area: $1232 \mathrm{ft}^{2}\left(115 \mathrm{~m}^{2}\right)$
}


Measured Annual Total kWh: (all end uses) 9323 kWh; 25.5 kWh/Day

Measured Annual Natural Gas Therms: (All end uses) None

Other Energy Source Use: None

Year of Measurement (12 month period) Jan 12006 - Dec. 31, 2006

Normalized Total Annual Energy Use: $81.1 \mathrm{kWh} / \mathrm{m}^{2}$

Annual kWh Solar Electric Production: $2739 \mathrm{kWh}$

Net Electricity Use: 6584 kWh (18 kWh/Day)

Normalized Net Energy Use: $57.3 \mathrm{kWh} / \mathrm{m}^{2}$

Primary Design Features (Energy Efficiency): foundation geothermal heat pump system, ZEHcor wall, Structural Insulated Panel roof and walls, air-tight construction, ASHRAE 62.2 mechanical ventilation compliant, reflective raised metal roofing, interior duct system, High performance windows, efficient lighting and appliances.

Primary Design Features (Renewable Energy): solar water heater; 2.2 kW PV system (facing south on $4 / 12$ pitch roof)

Estimated Incremental Cost of Construction: \$54,676

Estimated Incremental Cost of any Solar Features: (include both solar hot water and PV): $\$ 18,000$

Other Project Comments:

\section{Site Designation: ZEH4 Zero Energy Home}

Location: Lenoir City, TN

Contact: Jeff Christian (ChristianJE@ORNL.gov)

Year of Construction: 2004

Conditioned Floor Area: $1200 \mathrm{ft}^{2}\left(112 \mathrm{~m}^{2}\right)$

Measured Annual Total kWh: (all end uses) 8286 kWh; 22.7 kWh/DayMeasured Annual

Natural Gas Therms: (All end uses) None

Other Energy Source Use: None

Year of Measurement (12 month period) Dec 12005 - Nov. 30, 2006

Normalized Total Annual Energy Use: $74 \mathrm{kWh} / \mathrm{m}^{2}$

Annual kWh Solar Electric Production: $2763 \mathrm{kWh}$

Net Electricity Use: 5523 kWh (15.1 kWh/Day)

Normalized Net Energy Use: $49.3 \mathrm{kWh} / \mathrm{m}^{2}$

Primary Design Features (Energy Efficiency): Heat-Pump Water Heater, Air-source SEER 17 heat pump system, Structural Insulated Panel roof and above-grade walls, Precast insulated concrete panels for the walkout lower level, Cool-coating applied to the exterior surface of the exposed above-grade lower level panels, air-tight construction, ASHRAE 62.2 mechanical ventilation compliant, reflective metal roofing, interior duct system, High performance windows, efficient lighting and appliances.

Primary Design Features (Renewable Energy): 2.2 kW PV system (facing south on 4/12 pitch roof)

Estimated Incremental Cost of Construction: \$27,816

Estimated Incremental Cost of any Solar Features: (include both solar hot water and PV):

PV cost $\$ 15,000$ 


\section{Site Designation: ZEH3 Zero Energy Home}

Location: Lenoir City, TN

Contact: Jeff Christian (ChristianJE@ORNL.gov)

Year of Construction: 2003

Conditioned Floor Area: $1082 \mathrm{ft}^{2}\left(101 \mathrm{~m}^{2}\right)$

Measured Annual Total kWh: (all end uses) 11014 kWh; 30.2 kWh/Day

Measured Annual Natural Gas Therms: (All end uses) None

Other Energy Source Use: None

Year of Measurement (12 month period) March 12004 - Feb. 28, 2005

Normalized Total Annual Energy Use: $109 \mathrm{kWh} / \mathrm{m}^{2}$

Annual kWh Solar Electric Production: $2241 \mathrm{kWh}$

Net Electricity Use: 8773 kWh $(24$ kWh/Day)

Normalized Net Energy Use: $87 \mathrm{kWh} / \mathrm{m}^{2}$

Primary Design Features (Energy Efficiency): Geothermal Heat-Pump with a desuperheater connected to the Water Heater, Air-source SEER, Structural Insulated Panel roof and above-grade walls, Insulated unvented crawl space, Infrared reflective pigmented coating applied to raised metal seam roof, air-tight construction, ASHRAE 62.2 mechanical ventilation compliant, interior duct system, High performance windows, efficient lighting and appliances.

Primary Design Features (Renewable Energy): 2.0 kW PV system (facing south on 6/12 pitch roof)

Estimated Incremental Cost of Construction: \$45,728.40

Estimated Incremental Cost of any Solar Features: (include both solar hot water and PV):

PV cost $\$ 16,000$

Site Designation: ZEH2 Zero Energy HomeLocation: Lenoir City, TN

Contact: Jeff Christian (ChristianJE@ORNL.gov)

Year of Construction: 2003

Conditioned Floor Area: $1082 \mathrm{ft}^{2}\left(101 \mathrm{~m}^{2}\right)$

Measured Annual Total kWh: (all end uses) 12207 kWh; 33.4 kWh/Day

Measured Annual Natural Gas Therms: (All end uses) None

Other Energy Source Use: None

Year of Measurement (12 month period) April 12004 - March 31, 2005

Normalized Total Annual Energy Use: $120.9 \mathrm{kWh} / \mathrm{m}^{2}$

Annual kWh Solar Electric Production: 2305 kWh

Net Electricity Use: 9902 kWh (27.1 kWh/Day)

Normalized Net Energy Use: $98 \mathrm{kWh} / \mathrm{m}^{2}$

Primary Design Features (Energy Efficiency): Heat Pump Water heater linked to the Energy Star Refrigerator and the Crawl space controlled by the thermostat to provide supplementary space cooling and dehumidifing in the summer and serve as a radon mitigator in the heating mode, SEER 14 2-speed compressor Heat-Pump Air-source, Structural Insulated Panel roof and above-grade walls, Insulated unvented crawl space, ASHRAE 62.2 mechanical ventilation compliant, interior duct system, High performance 
windows, efficient lighting and appliances.

Primary Design Features (Renewable Energy): 2.0 kW PV system (facing south on 6/12

pitch roof)

Estimated Incremental Cost of Construction: \$39,357.80

Estimated Incremental Cost of any Solar Features: (include both solar hot water and PV):

PV cost $\$ 16,000$

\section{Site Designation: ZEH1 Zero Energy Home}

Location: Lenoir City, TN

Contact: Jeff Christian (ChristianJE@ORNL.gov)

Year of Construction: 2002

Conditioned Floor Area: $1056 \mathrm{ft}^{2}\left(98 \mathrm{~m}^{2}\right)$

Measured Annual Total kWh: (all end uses) 10,216 kWh; 28 kWh/Day

Measured Annual Natural Gas Therms: (All end uses) None

Other Energy Source Use: None

Year of Measurement (12 month period) March 12003 - Feb. 29, 2004

Normalized Total Annual Energy Use: $104.2 \mathrm{kWh} / \mathrm{m}^{2}$

Annual kWh Solar Electric Production: 2006 kWh

Net Electricity Use: 8210 kWh (27.1 kWh/Day)

Normalized Net Energy Use: $84 \mathrm{kWh} / \mathrm{m}^{2}$

Primary Design Features (Energy Efficiency): Heat Pump Water heater linked to the Energy Star Refrigerator and the Crawl space controlled by the thermostat to provide supplementary space cooling and dehumidifing in the summer and serve as a radon mitigator in the heating mode, SEER 13 Heat-Pump Air-source, Structural Insulated Panel roof, walls and the floor, Unvented crawl space, ASHRAE 62.2 mechanical ventilation compliant, interior duct system, High performance windows, efficient appliances, Grey water waste heat recovery system.

Primary Design Features (Renewable Energy): $2.0 \mathrm{~kW}$ PV system (facing south on 4/12 pitch roof)Estimated Incremental Cost of Construction: \$39,198

Estimated Incremental Cost of any Solar Features: (include both solar hot water and PV):

PV cost $\$ 14,500$

\section{Site Designation: Armory Park del Sol ZEH}

Location: Tucson, AZ

Contact: Joe Wiehagen, NAHB, Jwiehagen@nahbrc.org

Year of Construction: 2003

Conditioned Floor Area: $1718 \mathrm{ft}^{2}\left(160 \mathrm{~m}^{2}\right)$

Measured Annual Total kWh: (all end uses) 8786 kWh; 24.1 kWh/Day

Measured Annual Natural Gas Therms: (All end uses) None

Other Energy Source Use: None

Year of Measurement (12 month period) 2005 - 2006

Normalized Total Annual Energy Use: $54.9 \mathrm{kWh} / \mathrm{m}^{2}$

Annual kWh Solar Electric Production: 7207 kWh 
Net Electricity Use: 1578 kWh (4.3 kWh/Day)

Normalized Net Energy Use: $9.9 \mathrm{kWh} / \mathrm{m}^{2}$

Primary Design Features (Energy Efficiency): High efficiency 2 speed air conditioner, R-41 ceiling under white reflective roofing, R-14 exterior insulation over filled concrete blocks, interior duct system, high performance windows, efficient lighting and appliances.

Primary Design Features (Renewable Energy): 4.2 kW PV system; 120 sqft solar thermal collectors with 220 gallon storage for DHW and space heating; electric resistance backup Estimated Incremental Cost of Construction: \$9,500

Estimated Incremental Cost of any Solar Features: (include both solar hot water and PV): PV cost $\$ 42,000$

\section{Site Designation: Smith/Klingenberg Passivhaus}

Location: Urbana, IL

Contact: Katrin Klingenberg (katrin.klingenberg@e-colab.org)

Year of Construction: 2002-2003

Conditioned Floor Area: 1200 sqft (111.5 sqm)

Measured Annual Total kWh: (all end uses) $4350 \mathrm{kWh}$ or $39 \mathrm{kWh} / \mathrm{sqm}$ and year (of that $10.7 \mathrm{kWh} / \mathrm{sqm}$ and year are for space conditioning)

Measured Annual Natural Gas Therms: (All end uses) 0

Year of Measurement (12 month period) 2005

Annual kWh Solar Electric Production: 0

Primary Design Features (Energy Efficiency): Superinsulation, airtightness 0.6 ACH

@50Pa, passive solar, HRV with 100' Earth tube air intake for pre-warming in winter, cooling/dehumidification in summer, triple pane, argon filled low-e windows with insulated fiberglass frames, multi lock doors and windows, concrete slab on grade finished floor Primary Design Features (Renewable Energy): 0 Estimated Incremental Cost of Construction: approx. \$15 per sq ft Estimated Incremental Cost of any Solar Features: 0 Other Project Comments: First US passive house project to be entered into the first English version of the PHPP (Passive House Planning Package)

Project Weblink: e-colab.org

\section{Site Designation: Wheat Ridge ZEH}

Location: Wheat Ridge, Colorado (near Denver)

Contact: Paul Norton, Paul_Norton@NREL.gov

Year of Construction: 2005

Conditioned Floor Area: $1280 \mathrm{ft}^{2}\left(118.9 \mathrm{~m}^{2}\right)$

Measured Annual Total kWh: (all end uses): $3585 \mathrm{kWh}$

Measured Annual Natural Gas Therms: (All end uses): 57 Therms (1670 kWh)

Year of Measurement (12 month period): April 2006- March 2007

Annual kWh Solar Electric Production: $5127 \mathrm{kWh}$

Net Electricity Use: -1542 kWh (-13.0 kWh/Day)

Normalized Net Energy Use: $1.1 \mathrm{kWh} / \mathrm{m}^{2}$ 
Primary Design Features (Energy Efficiency): (list) superinsulation (R-60 ceiling, R-40 walls, R-30 floors), U=0.3 windows; ERV; tankless gas DHW auxiliary, direct vent ductless gas heater in home, CFL used for lighting throughout, Energy Star clothes washer and dishwasher

Primary Design Features (Renewable Energy): (list) large solar DHW system with 200 gallon (757 l) storage; 4 kW PV system

Estimated Incremental Cost of Construction: \$3,443

Estimated Incremental Cost of Solar Features: (include both solar hot water and PV): $\$ 39,068$

Other Project Comments: One of the first buildings to prove their attainment of zero energy on an annualized basis. When calculations are based on source energy, consumption was -24\% given the excess electrical production.

Project Weblink:

http://www.eere.energy.gov/buildings/building_america/cfm/project.cfm/state=CO/city=W heatridge/full=Colorado/project=Habitat\%20for\%20Humanity\%20\%20NREL\%20ZEH/ID=3690/floor_plan=4700\%20Carr\%20St\%20Plan\%20\%201130\%20sq.\%20ft\#house

\section{Site Designation: Premier Gardens Homes}

Location: Rancho Cordova, CA, (near Sacramento)

Contact: Rob Hammon, BIRA/CONSOL (rob@ConSol.ws)

Year of Construction: 2003, 95 homes of which 18 were monitored

Conditioned Floor Area: Avg $1770 \mathrm{ft}^{2}\left(164 \mathrm{~m}^{2}\right)$

Measured Annual Total kWh: (all end uses) 7,066 kWh; 19.4 kWh/Day

Measured Annual Natural Gas Therms: (All end uses) 277 Therms

Other Energy Source Use: None

Year of Measurement (12 month period) 2004

Normalized Total Annual Energy Use: $89.8 \mathrm{kWh} / \mathrm{m}^{2}$

Annual kWh Solar Electric Production: 3,329 kWh

Net Electricity Use: 3,737 kWh (10.2 kWh/Day)

Normalized Net Energy Use: $70.1 \mathrm{kWh} / \mathrm{m}^{2}$

Primary Design Features (Energy Efficiency): High efficiency SEER 14 air conditioner, high efficiency furnaces (AFUE=0.91) R-38 ceiling, R-13 to R-19 wall exterior insulation, ducts buried in attic insulation, high performance windows, $100 \%$ fluorescent lighting.

Primary Design Features (Renewable Energy): 2.4 kW PV system

Estimated Incremental Cost of Construction: \$3,200

Estimated Incremental Cost of any Solar Features: (include both solar hot water and PV): $\$ 15,636$

Comment: Compared to monitored adjacent community (Cresleigh) without features which showed 10\% higher electricity use (7770 kWh) and 64\% higher gas consumption (454 Therms). Electricity use is $17 \%$ lower than PGE average for houses this size (8550 kWh); gas consumption is $49 \%$ lower (540 Therms)

Weblink: http://media.pennnet.com/documents/Solar+data.pdf 